\title{
Reflective practice: The enduring influence of Kolb's Experiential Learning Theory
}

\section{Paul Dennison}

Business School

Since 1984 David Kolb's Experiential Learning Theory (ELT) has been a leading influence in the development of learner-centred pedagogy in management and business. It forms the basis of Kolb's own Learning Styles' Inventory and those of other authors including Honey and Mumford (2000). It also provides powerful underpinning for the emphasis, nay insistence, on reflection as a way of learning and the use of reflective practice in the preparation of students for business and management and other professions. In this paper, we confirm that Kolb's ELT is still the most commonly cited source used in relation to reflective practice. Kolb himself continues to propound its relevance to teaching and learning in general. However, we also review some of the criticisms that ELT has attracted over the years and advance new criticisms that challenge its relevance to higher education and its validity as a model for formal, intentional learning.

\section{Kolb's Experiential Learning Theory}

Kolb's ELT first appeared in his book Experiential Learning: Experience as the Source of Learning and Development (1984). This now familiar diagram (Figure 1), owes much to Lewin's 1951 model for experiential learning (Figure 2). Kolb's model captured the mood of innovation in the 1980s in management development and training and was an instant success.

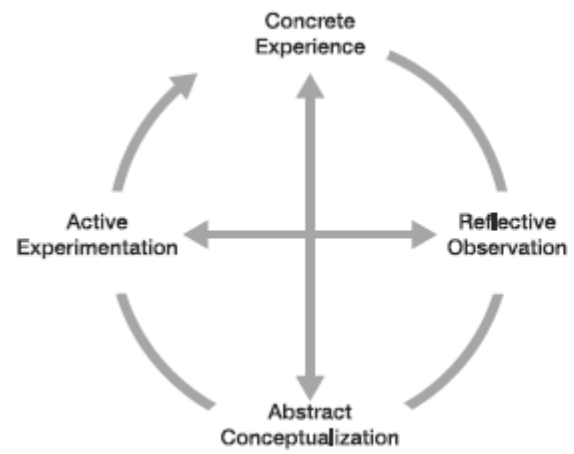

Figure 1: Kolb's ELT (1984).

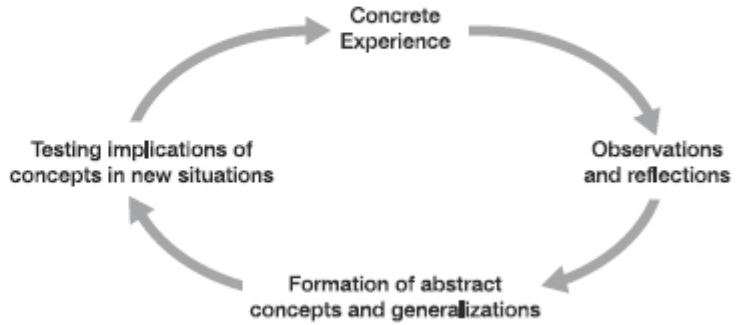

Figure 2: Lewin's Experiential Learning Model (1951). 
Some of the reasons for this are:

- It appeared to be grounded in reality - it was vocational - and denied the 'artificiality of the classroom'.

- It focused on the learner - it was learner-centred (which in 1984, made it 'cutting-edge').

- It advocated learning from 'experience' and learning by doing.

- It appeared to empower the learner, who could dispense with 'tutor control'.

- Its model for learning mimicked true discovery, which at a stroke removed the 'artificial' distinction between research and learning.

That it is still widely used was, perhaps, the most striking result of the small-scale study that was one of the starting points for this paper.

\section{The study and its findings}

A pilot study of ten interviews was conducted among lecturers from three departments in the Business School, addressing the following broad areas of enquiry:

- To what extent and in which courses were students required to demonstrate reflective practice?

- Whether lecturers undertook or had undertaken written reflection themselves?

- How did students approach reflective practice? How seriously did they take it? What criteria did lecturers use to assess their reflections?

- Which authors/theories did lecturers offer students as underpinning the value of reflective practice to the practitioner?

Table 1: How students were required to demonstrate reflective practice.

\begin{tabular}{|c|c|c|c|c|}
\hline Course & $\begin{array}{l}\text { Programme/ } \\
\text { stage }\end{array}$ & Referent & $\begin{array}{l}\text { Guide length } \\
\text { (words) }\end{array}$ & Weighting \\
\hline $\begin{array}{l}\text { Continuing Professional } \\
\text { Development }\end{array}$ & CIPD & CPD Learning Log & 4000 & $100 \%$ \\
\hline $\begin{array}{l}\text { Personal \& Professional } \\
\text { Development } 2\end{array}$ & SMS Year 2 & Pieces of reflection & $3 \times 2000$ & $100 \%$ \\
\hline $\begin{array}{l}\text { Professional Update \& } \\
\text { Development }\end{array}$ & MBA & Reflective Portfolio & $8 \times 500$ & $100 \%$ \\
\hline $\begin{array}{l}\text { Personal \& Professional } \\
\text { Development } 2\end{array}$ & Man Year 2 & Learning Journal & 800 & $15 \%$ \\
\hline Strategy & MA & Reflective Report & 250 & $10 \%$ \\
\hline $\begin{array}{l}\text { Management Information } \\
\text { Systems }\end{array}$ & Year 2 & Reflective Report & 500 & $10 \%$ \\
\hline $\begin{array}{l}\text { Process Control } \\
\text { Management }\end{array}$ & Year 2 & Critical Reflection & 500 & $5 \%$ \\
\hline Strat Financial Management & Year 3 & Reflection on presentations & 300 & Part of $15 \%$ \\
\hline
\end{tabular}


Table 1 illustrates the degree to which reflective practice is employed in courses. Table 1 identifies two configurations: For a few courses, reflective practice formed 100 per cent of the assessment; for a larger group, it formed a minority element - less than 20 per cent.

\section{Lecturers' own experience and use of reflective practice}

Only 2 out of 10 lecturers actually undertook written reflective practice, although all pointed out that they were reflective in their work - and were required to be. Most had engaged in written reflective practice in their own educational history. There was an appreciation of the difficulty in assessing reflective practice; assessment was somewhat incongruous for an activity that was essentially a form of self-assessment or self-explanation. Reflective practice by its nature is personal, rather than public, and to intrude upon it for the purpose of assessment is unwelcome. On the other hand, remodelling reflective practice as 'public' for the purposes of assessment was invalid and probably self-defeating. Other authors had commented on this (Macfarlane and Gourlay, 2009).

Lecturers were in favour of retaining it, however, because they saw reflective practice as being at the heart of the concept of professionalism, which depends of on 're-assessing oneself and one's work continually, habitually'.

\section{How seriously did students take it?}

Lecturers reported great variation in the way students approached the reflective task. On the CIPD programme, with its emphasis on a reflective culture, students took it very seriously indeed, but elsewhere only a minority ( $<10$ per cent) of students did more than follow instructions in a formulaic way. Students from other cultures found it very difficult to understand.

\section{Criteria for assessment}

There was a corresponding divergence in grading criteria: reflective practice was often linked to other skills development and reflection was expected to focus on the developmental process. Lecturers looked for openness - admission of error, doubt or difficulty - self-awareness, insight into others - group dynamics and interactions - authenticity. Some lecturers had more developed expectations: One looked for 'enthusiasm, opinions and openness - the triangulation between these'; another identified a three stage model - 1. Simple description, 2. Relating present experience to previous experiences, 3 . Identifying learning and how to use it in the future.

\section{Authors cited in support of reflective practice}

The most commonly cited author on reflective practice was David A. Kolb (1984), whose Experiential Learning Theory (ELT), was mentioned by 6 out 10 of respondents, followed by Donald A. Schön's Reflective Practitioner (1983) with 4 out of 10. Other sources were much less well known (Cowan, 1998; Lewin, 1951) and the Johari Window (Luft and Ingham, 1955). Some textbooks treated reflective practice seriously (Cottrell, Megginson and Whitaker, 2007) and at least one internet site was used (Institute of Reflective Practice, 2003).

\section{Kolb's relevance today}

Twenty-five years later, my small-scale study reveals that Kolb's ELT is still regarded as relevant and influential by a substantial number - perhaps even the majority - of lecturers in business and management. His influence lives on and, although his exposition of ELT has migrated somewhat from the original experiential purity of 1984 , he is still adding to the literature surrounding the 
model (Kolb and Kolb, 1999; 2005; 2008; Kolb and Boyatzis, 2000). Indeed there is something of an industry built around the concepts of ELT - the International Consortium for Experiential Learning lists 19 other organisations - available at www.icel.org.uk.

ELT has not gone unchallenged over those twenty-five years. Several authors, including Kolb himself (1999), have published compilations of criticisms (see http://reviewing.co.uk/research/ experiential.learning.htm\#21).

Smith, for instance, (2001) grouped critiques of Kolb's ELT under six key issues:

1. It pays insufficient attention to the process of reflection (see Boud et al., 1985).

2. The claims made for the four different learning styles are extravagant (Jarvis 1987; Tennant, 1997).

3. The model takes very little account of different cultural experiences/conditions (Anderson, 1988).

4. The idea of stages or steps does not sit well with the reality of thinking. There is a problem here - that of sequence. As Dewey (1933) has said in relation to reflection, a number of processes can occur at once, stages can be jumped. This way of presenting things is rather too neat and is simplistic.

5. Empirical support for the model is weak (Jarvis, 1987; Tennant, 1997). The initial research base was small, and there have only been a limited number of studies that have sought to test or explore the model (such as Jarvis, 1987).

6. The relationship of learning processes to knowledge is problematic (Jarvis, 1987).

Coffield et al., (2004, p. 69), in their authoritative, critical review of learning styles and pedagogy in post-16 learning, dismissed ELT as the theoretical underpinning for Kolb's Learning Styles Inventory (LSI) with the remark 'the notion of a learning cycle may be seriously flawed'.

\section{New criticisms of ELT}

The context that suggests itself as one in which experiential learning is most likely to thrive is that of sport. Here is an arena where learning by doing is the norm, where the 'artificiality' of the classroom is acknowledged, where learning is learner-centred. It is also an arena where success in learning is instantly recognisable by success in competition; there is no need for assessment and evaluation of methods - the results of competition speak for themselves.

When this specific context is examined, what do we find? Serious sporting development is dominated by trainers - teachers. No serious sportsperson would begin development without one.

One role of the sports trainer is to provide informed feedback - the external view - to the sportsperson, so necessary if they are to improve. A yet more crucial role is the setting of a training agenda - showing the sportsperson what is involved in the process of learning to win. Both these roles are completely ignored by ELT, where presumably the trainer is merely part of the learning environment. ELT appears to advocate learner-centred sporting development by 'trial-and-error', which is slow and inefficient.

Dick Fosbury won the gold medal for high jump in the Olympics of 1968. It was the triumphant culmination of years of struggle to invent, perfect and get his 'Fosbury flop' technique accepted. That process was one of true discovery - difficult, lonely, uncertain. Today's high-jumper learns the 
Fosbury Flop much more quickly - it is neither difficult, nor lonely, nor uncertain. Their learning process is a pale shadow of the process of true discovery that Dick Fosbury went through. Now, it may well be that Dick Fosbury 'learned' - that is to say invented - his new technique by following something like ELT. The high jumpers that follow him do not.

Might it not be that Kolb's ELT is describing not learning but discovery? By designing learning situations with only the assumptions of a discovery situation, we are ignoring the advantages to the learning situation supplied by the teacher or trainer, those of:

- Setting the learning agenda

- Providing efficient feedback to the learner

- Giving an expert perspective on the learning situation.

These three advantages are crucial to success in 'formal intended learning situations' (Jarvis, 2004), the kind we commonly refer to collectively as higher education.

\section{Conclusions}

David Kolb's Experiential Learning Theory survives as a powerful influence in business and management, despite years of criticism and, among other things, is still the most commonly cited source justifying the use of reflective practice. Consideration of how learning takes place in the sporting arena - in particular the importance of a trainer/coach and crucial difference between learning and true discovery - suggests that ELT is not a useful model for higher education, that its attractions (learner-centredness, grounded in 'reality', the need for a teacher down-graded) are partly illusory. Learning is and needs to be, far more efficient than true discovery. The person of a teacher/trainer is central to this gain in efficiency by providing the agenda, the feedback and guidance, and another perspective to the learning situation.

The use of reflective practice for the purposes of assessment is widespread in business and management courses, but this brings problems. Lecturers find it difficult to assess and students find it difficult to undertake in an assessed context. Despite this, reflective practice is felt to be valuable because of the professionalism it instils. In the current culture, it is argued that the only way to 'drive' reflective practice is to assess it; if so, then perhaps there is something amiss in the current culture.

\section{References}

Anderson, J. A. (1988) 'Cognitive Styles and Multicultural Populations'. Journal of Teacher Education, 39(1): 2-9.

Boud, D. Keogh, R. and Walker, D. (eds.) (1985) Reflection. Turning Experience into Learning, London: Kogan Page.

Coffield, F. Moseley, D. Hall, E. and Ecclestone, K. (2004) Learning Styles and Pedagogy in Post-16 Learning: A Systematic and Critical Review. London: LSR

Cottrell, S. (2003) The Study Skills Handbook (2nd edition). Basingstoke: Palgrave Macmillan. Cowan, J. (1998) On Becoming an Innovative University Teacher: Reflection in Action. Buckingham: SRHE and OUP. 
Dewey, J. (1933) How We Think. A Restatement of the Relation of Reflective Thinking to the Educative Process (revised edition). Boston: Heath.

Honey, P. Mumford, A. (2000) The Learning Styles Questionnaire: 80-item version. Maidenhead: Peter Honey Publications.

Institute of Reflective Practice. Available at www.reflectivepractices.co.uk.

Jarvis, P. (1987) Adult Learning in the Social Context. London: Croom Helm.

Jarvis, P. (2004) Adult Education and Lifelong Learning: Theory and Practice (3rd edition). London: Routledge Falmer.

Kolb, D.A. (1984) Experiential Learning: Experience as the Source of Learning and Development. New Jersey: Englewood Cliffs, Prentice-Hall.

Kolb, D.A. and Boyatzis, R.E. (2000) 'Experiential Learning Theory: Previous Research and New Directions' in Sternberg, R.J. and Zhang, L.F. (eds.) Perspectives on Cognitive Learning and Thinking Styles. New Jersey: Lawrence Erlbaum.

Kolb, A. and Kolb, D.A. (1999) Bibliography of Research on ELT and the Learning Style Inventory. Department of Organisational Behaviour, Weatherhead of School of Management, Case Western Reserve University, Cleveland, Ohio.

Kolb, A.Y. and Kolb, D.A. (2005) 'Learning Styles and Learning Spaces: Enhancing Experiential Learning in Higher Education'. Academy of Management Learning and Education, 4(2): 193-212.

Kolb, A.Y. and Kolb, D.A. (2008) 'Experiential Learning Theory: A Dynamic Holistic Approach to Management Learning, Education and Development' in Armstrong, S.J. and Fukami, C. (eds.) Handbook of Management Learning, Education and Development. London: Sage Publications.

Luft, J. and Ingham, H. (1955) 'The Johari Window, A Graphic Model of Interpersonal Awareness', Proceedings of the Western Training Laboratory in Group Development. Los Angeles: UCLA.

Macfarlane, B. and Gourlay, L. (2009) 'The Reflection Game: Enacting the Penitent Self'. Teaching in Higher Education, 14(4); 455-459.

Megginson, D. and Whitaker, V. (2007) Continuing Professional Development (2nd edition). London: Chartered Institute of Personnel and Development.

Schön, D. (1983) The Reflective Practitioner. How Professionals Think in Action. London: Temple Smith.

Smith, M. K. (2001) 'David A. Kolb on Experiential Learning'. The Encyclopedia of Informal Education. Online. Available at www.infed.org/biblio/b-explrn.htm.

Tennant, M. (1997) Psychology and Adult Learning 2e, London: Routledge. Online. www.infed.org/biblio/b-explrn.htm. 